\title{
Pro-autophagic signal induction by bacterial pore-forming toxins
}

\author{
Nicole Kloft · Claudia Neukirch • Wiesia Bobkiewicz • \\ Gunnaporn Veerachato · Tim Busch • \\ Gisela von Hoven $\cdot$ Klaus Boller $\cdot$ Matthias Husmann
}

Received: 13 April 2010 / Published online: 8 May 2010

(C) The Author(s) 2010. This article is published with open access at Springerlink.com

\begin{abstract}
Pore-forming toxins (PFT) comprise a large, structurally heterogeneous group of bacterial protein toxins. Nucleated target cells mount complex responses which allow them to survive moderate membrane damage by PFT. Autophagy has recently been implicated in responses to various PFT, but how this process is triggered is not known, and the significance of the phenomenon is not understood. Here, we show that $S$. aureus $\alpha$-toxin, Vibrio cholerae cytolysin, streptolysin $\mathrm{O}$ and E. coli haemolysin activate two pathways leading to autophagy. The first pathway is triggered via AMP-activated protein kinase (AMPK). AMPK is a major energy sensor which induces autophagy by inhibiting the target of rapamycin complex 1 (TORC1) in response to a drop of the cellular ATP/AMP-ratio, as is also observed in response to membrane perforation. The second pathway is activated by the conserved eIF $2 \alpha$-kinase GCN2, which causes global translational arrest and promotes autophagy in response to starvation. The latter could be accounted for by impaired amino acid transport into target cells. Notably, PKR, an eIF2 $\alpha$-kinase which has been implicated in autophagy induction during viral infection, was also activated upon membrane perforation, and evidence was obtained that phosphorylation of $\operatorname{eIF} 2 \alpha$ is
\end{abstract}

N. Kloft and C. Neukirch contributed equally to this work.

N. Kloft · C. Neukirch · W. Bobkiewicz · G. Veerachato ·

T. Busch · G. von Hoven · M. Husmann ( $\square)$

Institute of Medical Microbiology and Hygiene,

University Medical Center, Johannes Gutenberg-University

Mainz, Hochhaus am Augustusplatz, 55131 Mainz, Germany

e-mail: husmann@uni-mainz.de; MattHusmann@web.de

K. Boller

Morphology Section, Department of Immunology,

Paul-Ehrlich-Institute, 63225 Langen, Germany required for the accumulation of autophagosomes in $\alpha$-toxin-treated cells. Treatment with 3 -methyl-adenine inhibited autophagy and disrupted the ability of cells to recover from sublethal attack by S. aureus $\alpha$-toxin. We propose that PFT induce pro-autophagic signals through membrane perforation-dependent nutrient and energy depletion, and that an important function of autophagy in this context is to maintain metabolic homoeostasis.

Keywords Autophagy · Pore-forming toxins · Starvation · AMPK $\cdot$ eIF2 $\alpha$-kinases $\cdot S$. aureus

\section{Introduction}

Pore-forming toxins (PFT) are important virulence factors of many pathogenic bacteria [1-4], and there is a growing interest in innate defense mechanisms against PFT [4, 5]. Various signaling pathways have been implicated in the survival of target cells [6-11], but both sensor and effector mechanisms remain incompletely understood. Based on the observation that target cells of PFT may recover from a substantial drop of cellular ATP, we have advanced the concept that the repair of membrane lesions is an important aspect of cellular defense against these toxins [12-14]. Following the discovery by Huffman et al. that p38 MAPK is important for the survival of $C$. elegans exposed to PFTproducing bacteria or of mammalian cells incubated with aerolysin [6], we found that $\mathrm{p} 38$ is required at an early stage after sublethal attack by $S$. aureus $\alpha$-toxin to promote metabolic recovery of the target cell. Curiously, p38 was not required for recovery from attack by streptolysin O (SLO), which forms much larger membrane pores, leading to the proposal that membrane repair is diverse [7]. Consistently, membrane lesions formed by streptolysin $\mathrm{O}$ (SLO) are 
reportedly internalized by a dynamin-independent mechanism [15], whereas those caused by $\alpha$-toxin are eliminated by dynamin-dependent endocytosis and subsequent exocytosis [16]. Although these findings provide potential explanations for the reconstitution of membrane integrity, the mechanisms involved in maintaining metabolic homoeostasis during transient membrane perforation remain to be investigated.

Recent work on Vibrio cholerae cytolysin (VCC) indicated that autophagy may play a role in the cellular defense against this toxin [17]. Autophagy is a disposal and recycling pathway in cells [18], which is characterized by the formation of autophagosomes, structures limited by two membrane-bilayers, enclosing endogenous or exogenous material, including aggregated molecules, damaged organelles, invading organisms or cytoplasm. Genetic approaches in yeast have identified some 30 genes that are involved in autophagy, and mammalian homologues have been identified for many of them. The mammalian protein LC3 (Atg8 in yeast) is thought to play an important role during autophagosome formation. Proteolytic cleavage of a precursor generates LC3-I, which is then conjugated at its C-terminal glycine with phosphatidylethanolamine, yielding LC3-II. The lipidated protein associates with the phagophorous membrane and promotes autophagosome formation, a process underlying complex regulation [19].

A major regulator of autophagy is the target of rapamycin (TOR), which integrates multiple signaling pathways involved in metabolic regulation [20]. TORC1 (TOR-complex 1) is activated under conditions that favour growth. If growth factors, nutrients and ATP are abundant, p70S6 K, a downstream-target of TORC1, is phosphorylated, promoting translation via phosphorylation of the ribosomal protein S6 and the eIF4E-binding protein 4E-BP. Conversely, starvation and energy depletion and several other triggers result in the dephosphorylation of S6 K and 4E-BP, translational arrest and induction of autophagy; for review, see [21-23]. For example, lowering of the cellular ATP/AMP ratio triggers phosphorylation of AMP-activated protein kinase (AMPK). Phospho-AMPK inhibits TORC1, leading to dephosphorylation of $\mathrm{S} 6 \mathrm{~K}$, reduced translation and enhanced autophagy.

Autophagy induction upon starvation or viral infection depends on a second pathway, which is triggered by eIF2 $\alpha$-kinases GCN2 and PKR, respectively [24]. Although the mechanisms of autophagy-induction via eIF $2 \alpha$-phosphorylation are not fully understood, crosstalk with the mTOR pathway may play a role. GCN2 (general control, non-derepressible), also termed eIF2 $\alpha$-kinase 4 (EIF2AK4), functions as a nutrient sensor. It is the only known eIF $2 \alpha$-kinase conserved from yeast to mammals, and is basically triggered by uncharged tRNAs. Three additional eIF $2 \alpha$-kinases have been identified in mammalian cells, which are activated by diverse types of stress [25, 26]: HRI (EIF2AK1) responds to heme deficiency, PKR (EIF2AK2) confers eIF2 $\alpha$ phosphorylation in response to double-stranded RNA, and PERK (EIF2AK3) is a sensor of ER-stress. Phosphorylation of eIF $2 \alpha$ causes global translational arrest; some genes are exempt from this process and instead become overexpressed [27, 28]. This so-called integrated stress response (ISR) is thought to prevent the accumulation of unfolded proteins during stress, to conserve energy and to reprogram gene expression. EIF2 $\alpha$ phosphorylation is critically involved in both innate and adaptive immunity [29-33]. It is also important for the downregulation of protein synthesis during hibernation [34] and for the formation of memory [35, 36].

How PFT trigger autophagy is not known. Regarding the function of autophagy, it was speculated that destruction of toxin was responsible for the pro-survival effect in target cells of VCC [37]. However, because autophagy is also of great importance for nutrient and energy homoeostasis [19], and because cellular recovery from an attack by $S$. aureus $\alpha$-toxin appears not to involve destruction of pore complexes [19], we questioned that the model proposed for VCC applies to $\alpha$-toxin. In the present work, we show that diverse PFT trigger sensors of energy depletion and starvation, which are established activators of autophagy. Thus, PFT trigger AMPK and the ISR, and evidence is presented that membrane perforation and dissipation of ion gradients play a critical role for activation of these pathways. Further, the possibility is raised that the amelioration of acute starvation and energy crisis are important functions of autophagy during cellular defense against $S$. aureus $\alpha$-toxin.

\section{Materials and methods}

Cells and media

$\mathrm{HaCaT}$ is a non-virally transformed human keratinocyte cell line, kindly provided by Prof. Dr. N. Fusenig (Deutsches Krebsforschungsinstitut (DKFZ), Heidelberg, Germany) [38]. Cos7 cells were from Deutsche Sammlung für Mikroorganismen und Zellen (DMSZ), Braunschweig, Germany, and CD14-deficient human bladder carcinoma cell line A498 was from Cell Lines Services (CLS), Heidelberg. Cells were cultured in DMEM with $10 \%$ fetal calf serum (FCS) in a humidified incubator with $5 \% \mathrm{CO}_{2}$. Experiments to evaluate the impact of potassium efflux in the activation of GCN2 were performed with custom-made potassium $\left[\mathrm{K}^{+}\right]$- hi medium containing $80 \mathrm{mM} \mathrm{K}^{+}$and correspondingly lower $\mathrm{Na}^{+}$(PAN Biotech $\mathrm{GmbH}$ ); normal medium is termed $\left[\mathrm{K}^{+}\right]-\mathrm{n}$ in the text. 
Reagents

Wild-type $\alpha$-toxin, single amino acid exchange mutant D152C, streptolysin O (SLO), Vibrio cholerae cytolysin (VCC) and E. coli haemolysin A (HlyA) were prepared, and the haemolytic activity was measured as described [39-42]. AlexaFluor546-labelling of $\alpha$-toxin was performed with reagents from Invitrogen.

Rabbit polyclonal antibodies against GCN2, phosphorylated GCN2 (p-GCN2), eIF2 $\alpha$ phosphorylated at serine 51 (p-eIF $2 \alpha$ ), eIF $2 \alpha$, phospho-p70S6 kinase (p-p70S6 K), p70S6 K, phospho-AMPK $\alpha$ (Thr172), AMPK $\alpha$ and horseradish peroxidase (HRP)-conjugated goat anti-rabbit IgG were purchased from Cell Signaling Technology. Rabbit antibody against GFP and mouse monoclonal anti-p62/ SQSTM1 were from Abcam, mouse antibody against $\beta$-actin was from Sigma, horseradish peroxidase (HRP)conjugated goat anti-mouse IgG was from Santa Cruz Biotechnology INC. The LC3-antibody was from Nanotools. Nigericin, monensin, 3-methyladenine (3-MA) and bafilomycin were purchased from Merck Biosciences, Schwalbach, Germany. The N-term-GADD34-expression plasmid [28] was obtained from Addgene.

\section{Western blots}

Subconfluent cell monolayers grown in 6-well plates were washed once in PBS and solubilized in situ by the addition of $80 \mu \mathrm{l}$ of $2 \times$ SDS-loading buffer $(10 \%(\mathrm{v} / \mathrm{v})$ glycerol, $5 \%(\mathrm{v} / \mathrm{v}) 2-\mathrm{ME}, 2 \%(\mathrm{w} / \mathrm{v})$ SDS and bromophenol blue). Western blots for the detection of phosphorylated and total AMPK, p70S6 K and GFP were performed as published elsewhere [43]. For the detection of p-GCN2, separation of proteins by SDS-PAGE (7.5\%) was followed by electroblotting onto nitrocellulose at $100 \mathrm{~mA}$ for $80 \mathrm{~min}$, a subsequent wash in PBS, blocking for $1 \mathrm{~h}$ at $\mathrm{RT}$ in 5\% BSA (w/v) in PBS, two brief washing steps in PBS, incubation with first antibody (rabbit-anti-pGCN2) over night at $4{ }^{\circ} \mathrm{C}$, three washing steps in PBS, $0.02 \%$ Tween 20 and incubation with goat anti-rabbit IgG HRP conjugate $(1: 1,000)$ in PBS with $5 \% \mathrm{BSA}$, for $1 \mathrm{~h}$ at RT. The membrane was washed three times in PBS containing 0.02\% Tween 20, and bound antibody was detected by ECL (Roche).

\section{${ }^{3}$ H-Leucine uptake}

HaCaT cells $\left(2 \times 10^{5}\right.$ per well $)$ were seeded into 24 -well culture dishes 1 day prior to treatment with $\alpha$-toxin (500 ng/ml) in complete medium for $15 \mathrm{~min}$ at $37^{\circ} \mathrm{C}$. Subsequently, toxin-containing medium was withdrawn, and cells were washed with PBS before $500 \mu$ of medium devoid of cold leucine, but supplemented with $7.5 \mu \mathrm{Ci}$ per well of L-[4, 5- $\left.{ }^{3} \mathrm{H}\right]$-leucine (GE Healthcare, Freiburg,
Germany), was added. Cells were incubated for 1, 2 or $3 \mathrm{~min}$ at $37^{\circ} \mathrm{C}$, washed three times with ice-cold PBS, lysed in $200 \mu \mathrm{l}$ of $0.1 \mathrm{~N} \mathrm{NaOH}$ and lysates were analysed in a liquid scintillation counter (Beckman).

\section{PKR phosphorylation assay}

Because phospho-PKR (p-PKR) antibodies yielded poor results, we employed an assay based on the incorporation of radioactive phosphate and precipitation of $\mathrm{p}$-PKR with double-stranded RNA-coated beads [44]. HaCaT cells $\left(5 \times 10^{5}\right)$ were seeded into T25-flasks 1 day before treatment with $\alpha$-toxin or D152C as indicated. Cells were washed with ice-cold PBS and lysed in lysis buffer $(20 \mathrm{mM}$ HEPES pH 7.5, $120 \mathrm{mM} \mathrm{KCl,} 5 \mathrm{mM} \mathrm{MgCl}_{2}, 1 \mathrm{mM}$ DTT, $0.5 \% \mathrm{NP} 40,2 \mu \mathrm{g} / \mathrm{ml}$ leupeptin, $50 \mu \mathrm{g} / \mathrm{ml}$ aprotinin, $25 \mathrm{U} / \mathrm{ml}$ RNase inhibitor) for $10 \mathrm{~min}$ on ice. Lysates were centrifuged and $200 \mu \mathrm{g}$ protein/supernatant were mixed with $50 \mu \mathrm{l}$ reaction buffer $(20 \mathrm{mM}$ HEPES pH 7.5, $120 \mathrm{mM} \mathrm{KCl}$, $5 \mathrm{mM} \mathrm{MgCl}, 1 \mathrm{mM}$ DTT, $10 \%$ glycerol) and $50 \mu \mathrm{ATP}$ mixture $\left(6 \mu \mathrm{Ci} \gamma-{ }^{32} \mathrm{P}-\mathrm{ATP}, 50 \mu \mathrm{M}\right.$ cold ATP in reaction buffer). After $15 \mathrm{~min}$ at $30^{\circ} \mathrm{C}$, polyI: $\mathrm{C}$ beads were added and incubated for $1 \mathrm{~h}$ at $4^{\circ} \mathrm{C}$ with agitation. Beads were washed four times with wash buffer (20 mM HEPES $\mathrm{pH}$ 7.5, $90 \mathrm{mM} \mathrm{KCl}, 300 \mathrm{mM} \mathrm{NaCl}, 0,1 \mathrm{mM}$ EDTA, $10 \%$ glycerol) and boiled for $5 \mathrm{~min}$ in $50 \mu \mathrm{l} 2 \times$ SDS-loading buffer. After centrifugation, proteins were separated by SDS-PAGE (10\%), and labelled proteins were revealed by fluorography using Amplify, FUJI super RX films and a Kodak amplifier screen.

Immunofluorescence microscopy

HaCaT cells were seeded on glass cover slips 1 day before transient transfection of EGFP-LC3 plasmid (kindly provided by Prof. Yoshimori, Research Institute for Microbial Diseases, Osaka) with jetPEI ${ }^{\mathrm{TM}}$ (Polyplus-transfection SA, France) as recommended by the supplier. After $24 \mathrm{~h}$, cells were treated as described in legends, washed with PBS, fixed with $2 \%$ paraformaldehyde for $10 \mathrm{~min}$ at room temperature, washed three times with PBS and embedded in Fluoroprep (bioMérieux ${ }^{\circledR}$ SA, France). Immunofluorescence microscopy was performed with a ZEISS Axiovert $200 \mathrm{M}$ microscope, using a Plan-Apochromat $100 \times / 1.4$ oil objective; digital images were acquired with a ZEISS AxioCam and processed with Axiovision software and Adobe photoshop. EGFP-LC3-positive puncta per cell, (for $n>30$ ), was enumerated using ImageJ software (NIH).

\section{Electron microscopy}

The procedure used for electron microscopy (EM) has been published elsewhere [45]. In brief, cells were fixed with 
$2.5 \%$ glutaraldehyde in PBS for $45 \mathrm{~min}$ at room temperature and embedded in Epon 812 according to standard protocols. Seventy nanometre ultrathin sections were cut, stained with $1 \%$ lead citrate and $2 \%$ uranyl acetate and finally analysed in Zeiss EM 902 electron microscope, equipped with TRS digital camera.

\section{ATP measurements}

HaCaT cells were seeded at a density of $2 \times 10^{4}$ per well into 96-well tissue culture plates, and cellular ATP was analysed with the Bioluminescence Assay Kit CLS II (Roche), using a Lumat 9705 instrument (Berthold Technologies, Bad Wildbad) as described [46].

\section{Replicates and statistical analysis}

All data are representative of at least two independent experiments. Two-tailed unpaired Student's $t$-test was employed to assess statistical significance of differences between mean values (Fig. 7c). Significance was assumed at $P \leq 0.05$.

\section{Results}

Transient response of AMPK and S6 K to sublethal membrane perforation by $S$. aureus $\alpha$-toxin

AMP-activated protein kinase (AMPK) is an obvious candidate mediator of autophagy in target cells of PFT, because it is activated upon lowering of the cellular ATP/AMP ratio and because PFT cause energy depletion $[12-14,46]$. Western blots of lysates from $\alpha$-toxin-treated HaCaT cells revealed transient phosphorylation of AMPK under conditions of reversible ATP loss (Fig. 1a, b), whereby the time of p-AMPK-dephosphorylation correlated with ensuing ATP replenishment.

Next, we analysed the phosphorylation status of p70S6K in cells treated with $S$. aureus $\alpha$-toxin. As depicted in Fig. 1c, p70S6K became dephosphorylated upon treatment with $\alpha$-toxin. This effect too was reversible within hours, in keeping with the notion that the treatment conditions chosen here led to sublethal, transient perforation of cells.

\section{Diverse PFT activate AMPK}

As expected from the fact that VCC, SLO and HlyA also cause a drop of cellular ATP levels, they too activated AMPK phosphorylation (Fig. $2 \mathrm{a}-\mathrm{c}$ ). As $\left[\mathrm{K}^{+}\right]-$hi media markedly reduced this effect, as shown here for SLO (Fig. 2b), efflux of potassium may be an upstream trigger of AMPK in response to PFT.

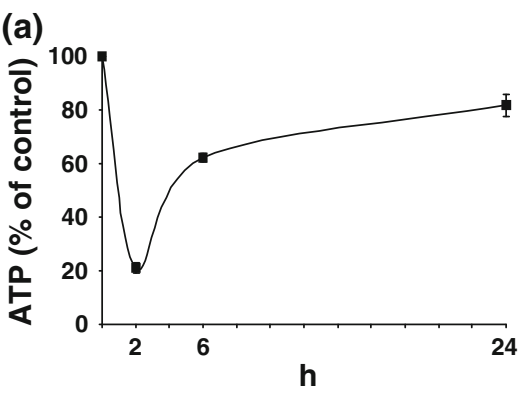

(b)

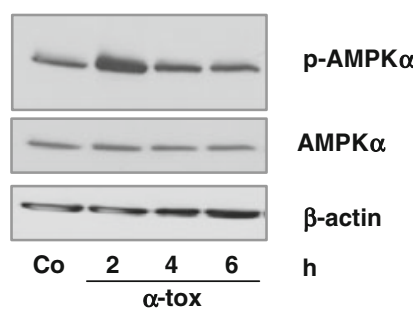

(c)

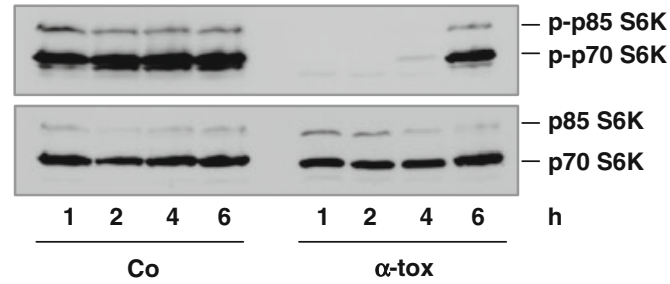

Fig. 1 Transient ATP loss is accompanied by transient AMPK phosphorylation and dephosphorylation of S6K. HaCaT cells were left untreated $(\mathrm{Co})$ or loaded with $\alpha$-toxin $(1 \mu \mathrm{g} / \mathrm{ml})$ for $40 \mathrm{~min}$ on ice, washed with ice-cold PBS and incubated in medium at $37^{\circ} \mathrm{C}$ for indicated times, before ATP levels were measured (a) or analysis of (p-) AMPK $\alpha$ by Western blot was performed (b); $\beta$-actin served as loading control. $\mathbf{c ~ H a C a T}$ cells were treated like in a, and phosphorylation of p70S6K was analysed by Western blot

S. aureus $\alpha$-toxin reduces the uptake of leucine

Because solute transport into cells depends on ion gradients [47], we reasoned that PFT might-apart from depleting cellular energy stores-also cause shortage of nutrients. Therefore, we measured net transport of radiolabelled leucine into $\alpha$-toxin-treated cells and found that accumulation of the amino acid was indeed retarded (Fig. 3a). Similar results were obtained with SLO (data not shown) suggesting that membrane pores of different size, structure and lifetime can reduce active nutrient transport into cells.

Membrane pore formation causes phosphorylation of GCN2 and PKR

Autophagy in response to lack of amino acids is regulated by GCN2 and downstream phosphorylation of eIF2 $\alpha$ at Ser51 [24]. GCN2 is activated by the binding of uncharged tRNAs, which leads to autophosphorylation of threonine 
(a)

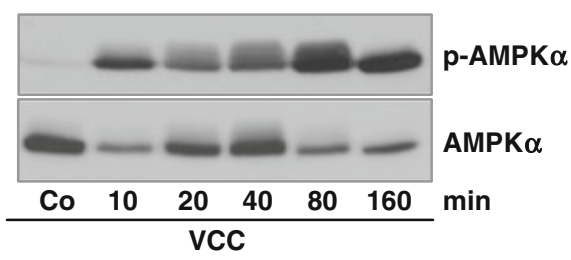

(b)

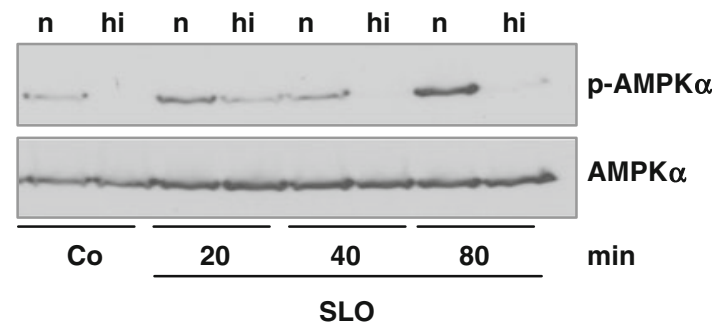

(c)

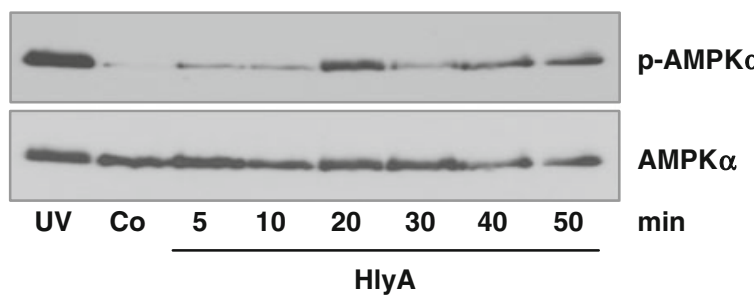

Fig. 2 Activation of AMPK by various PFT. a HaCaT cells were incubated with $100 \mathrm{ng} / \mathrm{ml} \mathrm{VCC}$ for indicated times, and the phosphorylation status of AMPK was analysed by Western blot. b HaCaT cells were treated with $1 \mu \mathrm{g} / \mathrm{ml} \mathrm{SLO}$ in $\left[\mathrm{K}^{+}\right]-\mathrm{n}$ or $\left[\mathrm{K}^{+}\right]$- hi media at $37^{\circ} \mathrm{C}$ for various times and analysed as in a. c A498 cells, which lack CD14 and are insensitive to LPS, were incubated with $160 \mathrm{ng} / \mathrm{ml}$ HlyA for the indicated periods and analysed as in a

residues within its activation loop. Western blots using antibodies against phospho-GCN2 revealed rapid and transient phosphorylation upon $\alpha$-toxin treatment whereby high concentrations of potassium in the extracellular milieu selectively blocked activation (Fig. 3b). A single amino acid exchange mutant, D152C, which binds to cells and

Fig. 3 a $S$. aureus $\alpha$-toxin inhibits leucine uptake. Accumulation of tritiated L-leucine was measured in $\mathrm{HaCaT}$ cells that were pre-treated with $\alpha$-toxin $(100 \mathrm{ng} / \mathrm{ml})$ for ten minutes. Columns indicate mean values of quadruplicate measurements; error bars indicate \pm SEM. The experiment was repeated with the same result. b Activation of GCN2 by $\alpha$-toxin. Cells were left untreated $(\mathrm{Co})$ or treated with toxin $(500 \mathrm{ng} / \mathrm{ml})$ in $\left[\mathrm{K}^{+}\right]-\mathrm{n}$ or $\left[\mathrm{K}^{+}\right]$-hi media for various times at $37^{\circ} \mathrm{C}$ before analysis of $(\mathrm{p}-) \mathrm{GCN} 2$ by Western blot. Cells exposed to the UV light $\left(312 \mathrm{~nm}, 70 \mathrm{~mJ} / \mathrm{cm}^{2}\right)$ of a Spectroline cross-linking apparatus, and subsequently incubated for $6 \mathrm{~min}$, served as a positive control (UV). c HaCaT cells were treated with mutant D152C (500 ng/ml) for various times and phosphorylated, and total GCN2 was analysed by Western blot. d, e Cells were treated with $100 \mathrm{ng} / \mathrm{ml} \mathrm{VCC} \mathrm{(d)} \mathrm{or}$ $250 \mathrm{ng} / \mathrm{ml} \mathrm{SLO}$ (e) for the indicated times and analysed like in $\mathbf{b}$. f A498 cells were incubated with HlyA $(160 \mathrm{ng} / \mathrm{ml})$ for various times and analysed as in b. $\mathbf{g} \mathrm{HaCaT}$ cells were treated with monensin $(25 \mu \mathrm{M})$ or nigericin $(6 \mu \mathrm{M})$ for the indicated periods, and subsequently analysed for p-GCN2 and GCN2 by Western blot assembles into heptamers, but is inefficient in forming trans-membrane pores [48], caused much less GCN2 phosphorylation (Fig. 3c).

Like $\alpha$-toxin, VCC, SLO and HlyA also activated GCN2 (Fig. 3d-f). Because there is evidence that potassium efflux is the common trigger of MAPK p38 in cells perforated by various PFT [49], we reasoned that it might also trigger GCN2 phosphorylation. As shown in Fig $3 \mathrm{~g}$, nigericine,

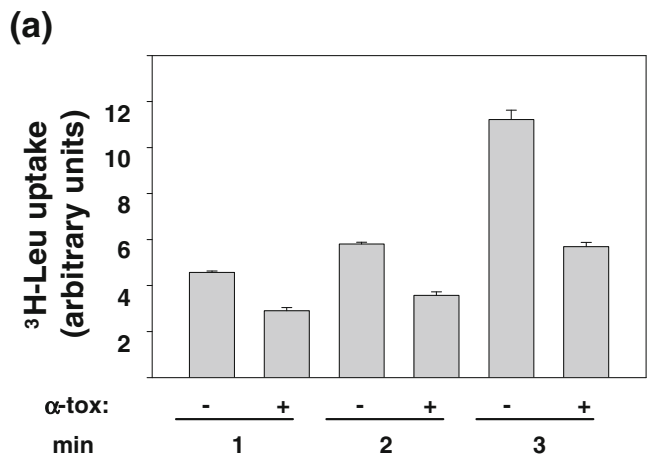

(b)

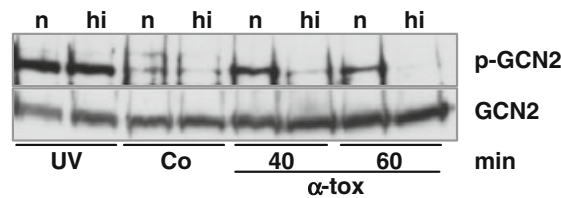

(c)

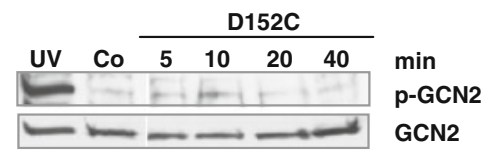

(d)

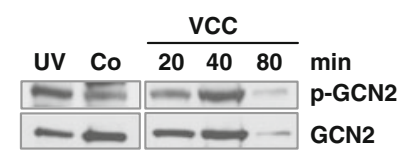

(e)

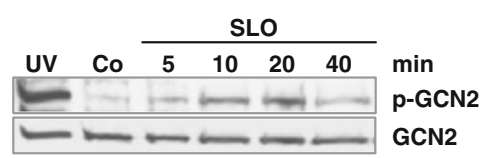

(f)

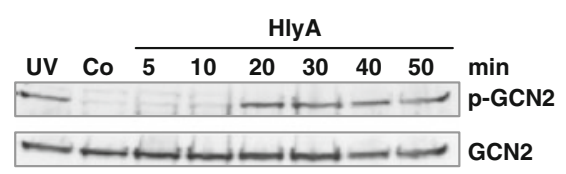

(g)

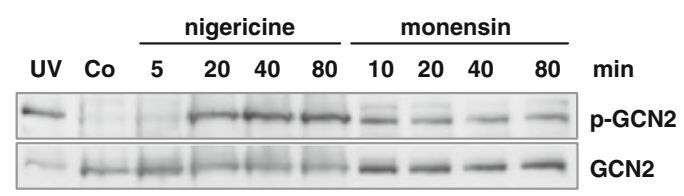


and to a lesser extent monensin, activated GCN2. Therefore, we conclude that disrupted cellular homoeostasis of the major monovalent cations leads to GCN2 phosphorylation.

Next, we sought to test whether in addition to GCN2 (EIF2AK4) other eIF $2 \alpha$-kinases are activated by $\alpha$-toxin. In line with results from $C$. elegans [9], phosphorylation of PERK (EIF2AK3) could not be discerned in $\alpha$-toxin-treated cells (data not shown). However, phosphorylation of the double-stranded RNA-binding kinase, PKR (EIF2AK2), was detectable by employing an assay based on ${ }^{32} \mathrm{P}$-ATPincorporation, pull-down of polyI:C-binding proteins, separation by SDS-PAGE and subsequent autoradiography (Fig. 4a). Pull-down with poly-C beads served as a control. Neither polyI:C, an activator of PKR in monocytes, nor $\mathrm{TNF} \alpha, \mathrm{H}_{2} \mathrm{O}_{2}$ or nigericine had a comparable effect as $\alpha$-toxin, suggesting that membrane perforation is a unique trigger of PKR in HaCaT cells. Thus, at least two eIF2 $\alpha$ kinases are activated by $\alpha$-toxin, both of which have been implicated in the induction of autophagy [19] and references therein.

Consistent with the above observations, eIF $2 \alpha$ became phosphorylated in response to PFT, which is exemplified here by the Western blot shown in Fig. $4 \mathrm{~b}$, where the response to $S$. aureus $\alpha$-toxin is shown.

(a)

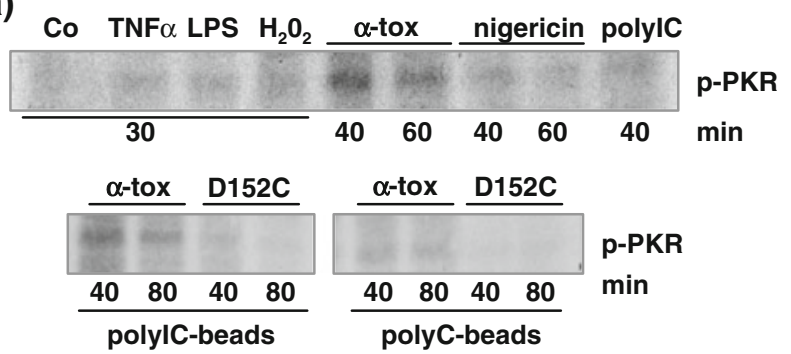

(b)

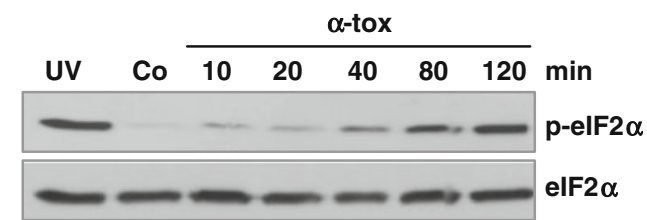

Fig. 4 a Activation of PKR by $\alpha$-toxin. Upper panel: HaCaT cells were treated with $\alpha$-toxin and phosphorylation of a double-stranded RNA-binding protein of apparent MW $75 \mathrm{kD}$ (referred to as PKR) was determined. Cells were incubated with the indicated agents for the times given below panels. Bottom set of panels: left PKR phosphorylation was determined as above, in cells treated with wild-type $\alpha$-toxin, or mutant D152C; right same treatment as left bottom panel, but poly$\mathrm{C}$ (instead of poly-I:C) beads were employed for precipitation, as a control. $\mathbf{b} \alpha$-toxin causes phosphorylation of eIF $2 \alpha$. HaCaT cells were loaded with $\alpha$-toxin on ice $(1 \mu \mathrm{g} / \mathrm{ml})$, washed and incubated for the indicated times before phosphorylation of eIF $2 \alpha$ at Ser51 was analysed by Western blot
Accumulation of autophagosomes upon attack by $S$. aureus $\alpha$-toxin depends on pore formation and eIF2 $\alpha$-phosphorylation, and is sensitive to 3-MA

Transmission-EM of $\alpha$-toxin-treated cells revealed many vacuoles, multivesicular bodies (MVB) and structures suggestive of autophagosomes or derivatives thereof (Fig. 5a).

Furthermore, double fluorescence experiments demonstrated that endocytosed AlexaFluor546- $\alpha$-toxin colocalized with EGFP-LC3-containing puncta (Fig. 5b). Similarly, labelled $\alpha$-toxin colocalized with p62/SQSMT1 (sequestosome1), a protein that serves as a linker between LC3 and ubiquitinated cytoplasmic material destined to be autophagocytosed (Fig. 5b). Toxin-negative vesicles containing p62 or LC3 were also more abundant in AlexaFluor546- $\alpha$-toxin-treated cells. Although the number of EGFP-LC3-puncta was markedly enhanced by incubating cells with $\alpha$-toxin $(200 \mathrm{ng} / \mathrm{ml})$, mutant D152C did not exert a significant effect at this concentration (Fig. 6a), suggesting that accumulation of autophagosomes in response to $\alpha$-toxin requires membrane pore formation. Accumulation of LC3-positive puncta in toxin-treated cells was confirmed using an antibody against endogenous LC3-II (data not shown). The effect of wild-type $\alpha$-toxin was reduced by 3-MA (Fig. 6a), suggesting that under the present conditions canonical pathways contributed to the accumulation of autophagy.

GCN2 and PKR are eIF2 $\alpha$-kinases known to activate autophagy in response to starvation and viral infection, respectively. Given that $\alpha$-toxin activated both kinases, it appeared likely that phosphorylation of eIF2 $\alpha$ played a role for the accumulation of autophagosomes in $\alpha$-toxintreated cells. If this was indeed the case, GADD34, a subunit of protein-phosphatase 1 that targets the catalytic subunit (pp1c) to eIF $2 \alpha$ (and thereby promotes eIF $2 \alpha$ dephosphorylation), should inhibit the effect of $\alpha$-toxin. This assumption was further fuelled by our earlier observation by serial analysis of gene expression (SAGE) that GADD34 transcript levels are induced in $\alpha$-toxin-treated $\mathrm{HaCaT}$ cells [46]. We cotransfected $\mathrm{HaCaT}$ cells with GADD34 and EGFP-LC3, and treated them with $\alpha$-toxin. Overexpression of GADD34 suppressed $\alpha$-toxin-dependent accumulation of EGFP-LC3-positive puncta (Fig 6b), whereas salubrinal, an inhibitor of GADD34, enhanced the number of autophagosomes even in the face of GADD34 overexpression (13 puncta per cell (median) in GADD34transfected cells receiving $\alpha$-toxin only vs. 30 puncta in cells receiving $\alpha$-toxin plus salubrinal). EGFP-LC3 was also recruited to $\alpha$-toxin-producing intracellular $S$. aureus (Fig. 6c), suggesting that some of the recent observations made in HeLa cells and CHO cells may also apply to HaCaT cells [50, 51]. 
Fig. 5 a TEM images of $\mathrm{HaCaT}$ cells. Left panel: untreated, size bar $1 \mu \mathrm{m}$; right: $\alpha$-toxin for $2 \mathrm{~h}$, size bar $500 \mathrm{~nm}$. b Digital fluorescence microscopic image of $\mathrm{HaCaT}$ cells treated with AlexaFluor546-labelled $\alpha$-toxin (red) for $2 \mathrm{~h}$. Left image sample was fixed and stained for $\mathrm{p} 62$ (green), by using AlexaFluor488-coupled secondary antibody. The image of the right panel was taken from cells which were transiently transfected with EGFP-LC3, and treated with AlexaFluor546- $\alpha$-tox as above. Arrows indicate colocalization of AlexaFluor546- $\alpha$-tox with p62, or EGFP-LC3-positive puncta, respectively. Untreated controls exhibited diffuse distribution of p62 (not shown), and of most EGFP-LC3 (see Fig. 6a) (a)
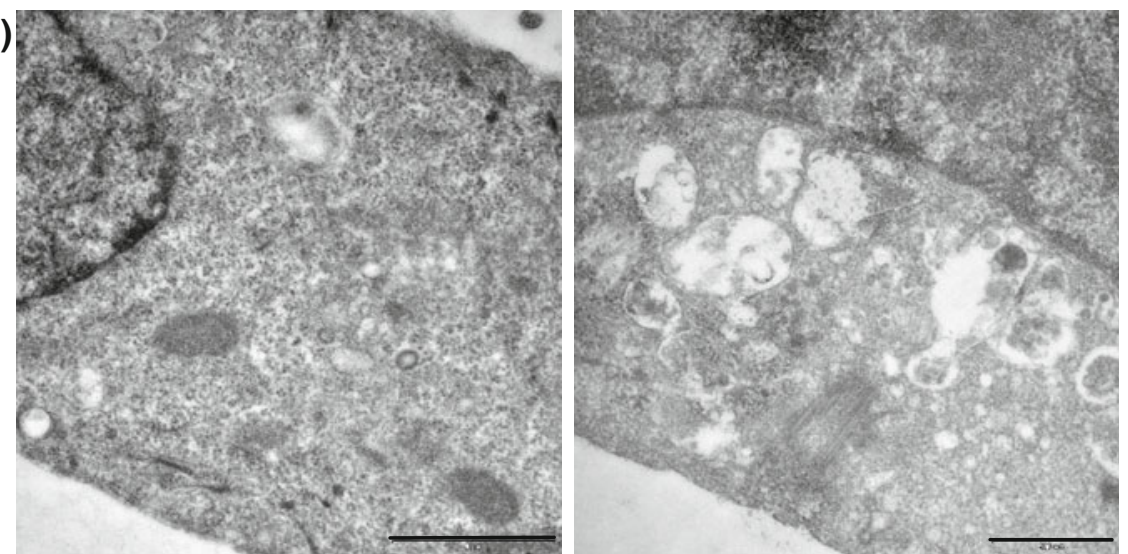

(b)
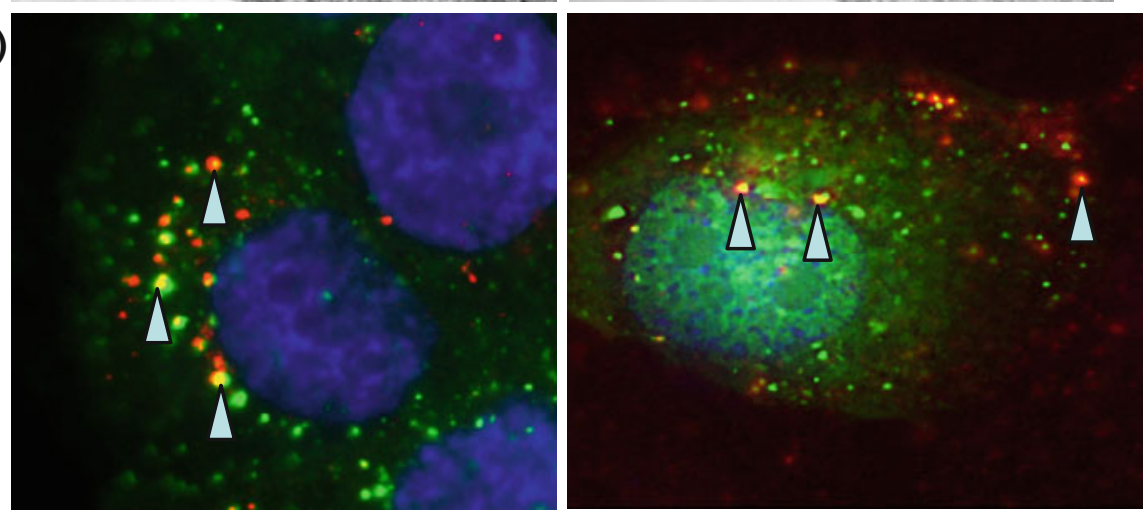

Next, we analysed the conversion of EGFP-LC3-I to EGFP-LC3-II by Western blot [52]. Samples receiving mutant toxin remained negative. Samples from $\alpha$-toxintreated cells gave a strong band corresponding to the lipidated form of EGFP-LC3. Although this effect was reduced by 3-MA (Fig. 7a), inhibition of endosomal acidification with the V-ATPase-inhibitor bafilomycin enhanced it (Fig. 7b).

The above results suggested that $\alpha$-toxin causes accumulation of autophagosomes in $\mathrm{HaCaT}$ cells, at least in part by enhancing autophagic flux, and by processes that are sensitive to the inhibition of PI3K. This prompted us to test the effect of 3-MA on the replenishment of intracellular ATP following sublethal $\alpha$-toxin attack. Cells were preincubated with 3-MA and subsequently treated with $\alpha$-toxin. Cellular ATP was measured 2 and $6 \mathrm{~h}$ after treatment. As shown in Fig. $7 \mathrm{c}$, the inhibitor strongly reduced the replenishment of cellular ATP observed in control cells.

\section{Discussion}

The principal result of this study is that membrane perforation triggers signals dedicated to the maintenance of energy and nutrient homoeostasis in cells. This provides a straightforward explanation for autophagy induction by PFT and helps to explain recovery after sublethal attack. Pro-auto- phagic signaling was readily observed under conditions of transient membrane perforation, with de-phosphorylation/ re-phosphorylation kinetics of S6K closely following the course of metabolic crisis and recovery. This strongly suggests that accumulation of autophagosomes in perforated cells is not simply due to a block at some maturation step, or of the fusion with lysosomes. Consistently, bafilomycin enhanced toxin-induced lipidation of EGFP-LC3. Accumulation of autophagosomes was documented by electron microscopy and by fluorescence microscopy using EGFPLC3 and antibodies against p62. Whereas autophagy-induction and colocalization with p62 have also been observed with listeriolysin [53, 54], a variant of aerolysin failed to recruit LC3 to membranes [55]. Clearly, further work is required to fully understand the requirements for autophagy induction by various PFT and the potential role of p62 and ubiquitination in this process.

We have shown previously that membrane perforation by various PFT induces loss of ATP in many cell types. Therefore, activation of AMPK and subsequent dephosphorylation of S6K in response to PFT did not come as a surprise. However, we show that PFT also activate GCN2. Although the established trigger of GCN2 in both mammalian and yeast cells is amino acid starvation [56], disturbances of ion homeostasis have been reported to activate the yeast homolog GCN2p [57, 58]. That amino acid transport into cells depends on ion gradients across the plasma 
(a)
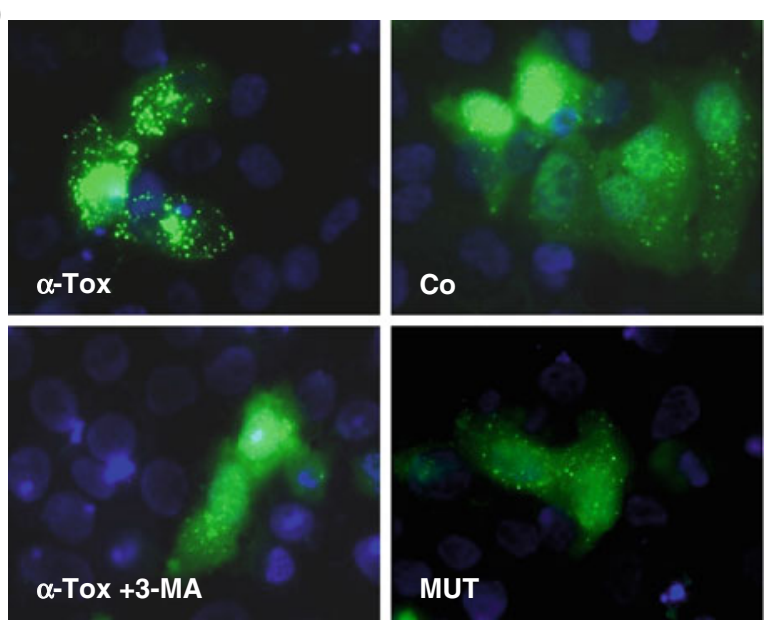

(b)
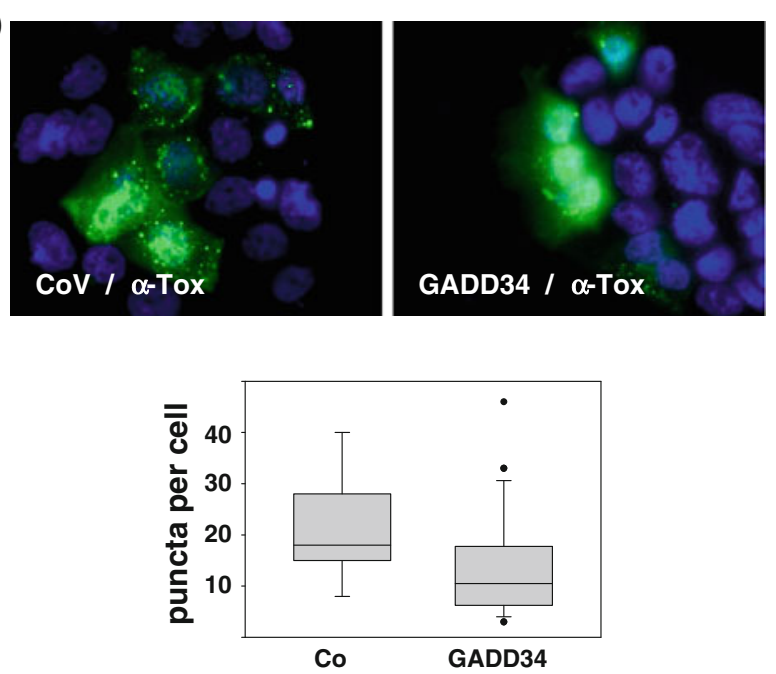

(c)

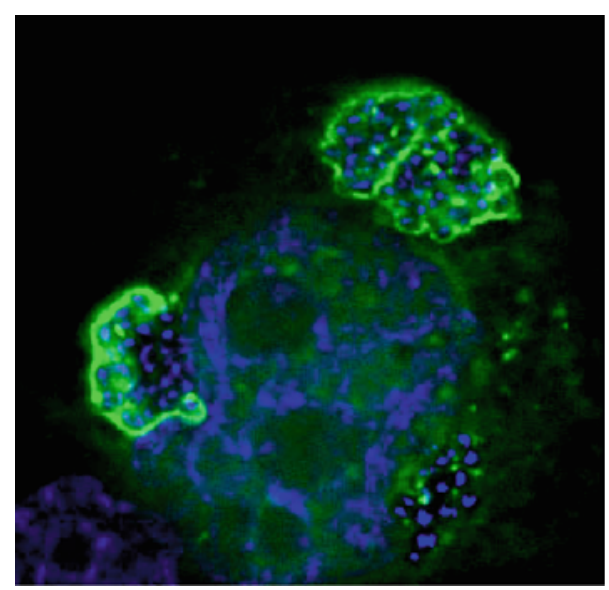

membrane [47] provides a potential link between these events, and consequently between membrane perforation and activation of GCN2. Most likely, transport of other nutrients including glucose is similarly affected by PFT.

A second eIF2 $\alpha$-kinase, PKR, was also activated by $\alpha$-toxin; however, the mechanism of activation remains to
Fig. 6 a HaCaT cells were transfected with EGFP-LC3 and treated with $200 \mathrm{ng} / \mathrm{ml}$ wild type ( $\alpha$-Tox), or D152C mutant (MUT) for $4 \mathrm{~h}$. ( $\mathrm{Co}$ ) denotes untreated sample and $(\alpha$-Tox +3 -MA) a sample pretreated with 3-MA $(10 \mathrm{mM})$ and then treated with $\alpha$-toxin in the presence of 3-MA. b Cells were transiently co-transfected with EGFP-LC3 and control vector $(\mathrm{CoV})$ or GADD34-expression vector, before treatment with $\alpha$-toxin as in $\mathbf{a}$. The box plot summarizes quantitation of data from $>30$ cells per treatment: the median number of puncta was 1.8fold higher in control cells. $\mathbf{c} \mathrm{HaCaT}$ cells were transfected as in a, incubated for $30 \mathrm{~min}$ with $\alpha$-toxin-producing $S$. aureus (plasmid-transformed derivative of DU1090 [39], 30 CFU/cell), washed with medium and incubated for $3 \mathrm{~h}$ at $37^{\circ} \mathrm{C}$. A representative digital fluorescence microscopic image is shown. Note juxta-nuclear accumulation of EGFP-LC3, decorating Hoechst-stained bacteria. No recruitment of EGFP-LC3 was observed when a $\alpha$-toxin-non-producing parental strain was employed (not shown)

(a)

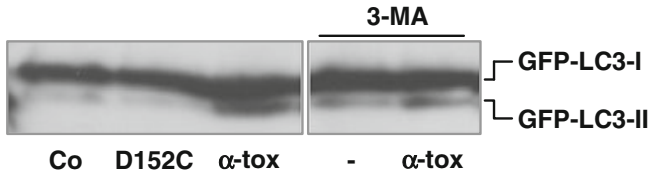

(b)

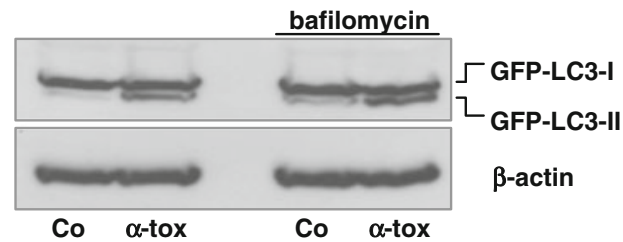

(c)

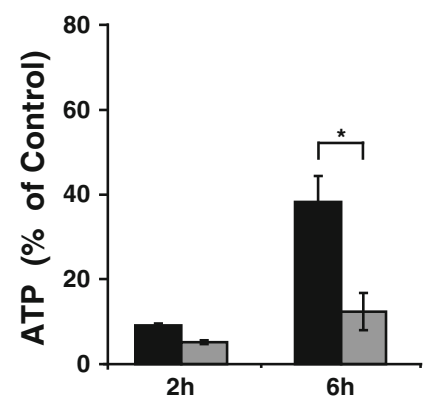

Fig. 7 a HaCaT cells were treated for $4 \mathrm{~h}$ with $200 \mathrm{ng} / \mathrm{ml} \alpha$-toxin or mutant toxin in the absence or presence of 3-MA, as indicated in the figure. The presence of EGFP-LC3-II was detected by Western blot. b $\mathrm{HaCaT}$ cells were treated with toxin as above, but in the presence or absence of bafilomycin $(200 \mathrm{ng} / \mathrm{ml})$. EGFP-LC3-II was analysed by Western blot. c 3-MA inhibits ATP recovery after $\alpha$-toxin attack. $\mathrm{HaCaT}$ cells were loaded with $\alpha$-toxin after pre-treatment with or w/o 3-MA $(10 \mathrm{mM})$ for $1 \mathrm{~h}$ and subsequently incubated at $37^{\circ} \mathrm{C}$ in the presence (grey) or absence (black) of 3-MA. Cellular ATP was determined after 2 and $6 \mathrm{~h}$. Data are mean values from four independent experiments; error bars indicate SEM, Asterisk denotes $P<0.05$

be elucidated. Because GADD34 overexpression reduced the accumulation of autophagosomes, while salubrinal enhanced it, eIF $2 \alpha$-phosphorylation appears to be involved in autophagy induction upon membrane perforation. The present data are the first to show that PFT trigger the ISR. Thus, PFT join LPS [33] and N-(3-oxo-acyl)homoserine 
lactones [59] in the list of bacterial products that can trigger this archaic stress response.

That membrane perforation is the common cause of proautophagic signal induction by PFT is suggested by the fact that structurally diverse toxins (SLO, HlyA and $\alpha$-toxin) yielded similar results. By using a single amino acid exchange mutant of $\alpha$-toxin which binds to cells, but is inefficient in pore formation, we show conclusively that membrane perforation is important for pro-autophagic signaling, accumulation of EGFP-LC3-positive puncta and lipidation of EGFP-LC3 in response to this PFT. Like in the case of p38, the efflux of potassium might be a common trigger for GCN2- and AMPK phosphorylation by PFT.

Previously, Schnaith et al. have observed that $S$. aureus induces autophagy in an $a g r$-dependent way [51]. Extending on this observation, Mestre et al. have recently reported that $S$. aureus $\alpha$-toxin is required for autophagy in mammalian cell lines infected with $S$. aureus [50], and here we have confirmed this observation for $\mathrm{HaCaT}$ cells. It was also observed that phagosome escape of $S$. aureus is $a g r$ dependent [60], and that $S$. aureus-containing or toxininduced autophagosomes are not acidified [50, 51]. The latter observation is reminiscent of our finding that $S$. aureus $\alpha$-toxin pore complexes are not degraded after endocytosis but released via exosome-like structures which we termed toxosomes [16]. However, in that study, we had also observed bafilomycin-sensitive degradation of $\alpha$-toxinmonomers, indicating that under conditions of sublethal perforation, $\alpha$-toxin does not fully paralyse the proteolytic machinery in human epithelial cells. Consistently, we found here that bafilomycin enhances EGFP-LC3-lipidation in $\alpha$-toxin-treated HaCaT cells. Because $\alpha$-toxin heptamers are rather resistant to proteolytic degradation under a broad range of conditions in vitro (our unpublished data), degradation of internalized heptamers is probably precluded, independent of a block of acidification.

It has been speculated that autophagy serves to degrade VCC [37]. Our previous work did not support the idea that this model applies to $S$. aureus $\alpha$-toxin pore complexes [16], and the recent data of Mestre et al. confirm our conclusion [50]. Our model envisaging the release of toxosomes is also not at odds with the observation that induction of autophagy by nutrient deprivation inhibits exosome secretion [61], because pro-autophagic signaling fades with ensuing toxosome release (this study and [16]). Actually, an autophagy-dependent mode of exocytosis has recently been described in yeast $[62,63]$. Therefore, we speculate that toxosome release might represent a manifestation of a similar pathway in mammalian cells.

3-MA inhibited the formation of EGFP-LC3-positive puncta and lipid-modified EGFP-LC3, suggesting that perforation of $\mathrm{HaCaT}$ cells with $\alpha$-toxin triggers the canonical pathway of autophagy. Replenishment of ATP in $\alpha$-toxin-

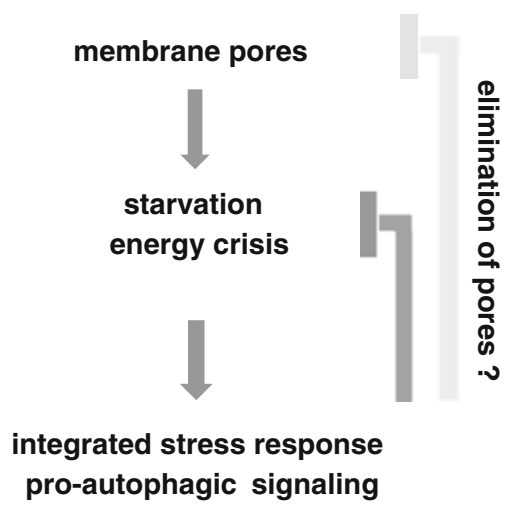

Fig. 8 Hypothetical model of induction and role of autophagy after membrane perforation by PFT: membrane perforation cuts nutrient supplies by paralysing ion gradient-dependent transport systems and causes energy loss. This leads to the activation of GCN2, AMPK and possibly additional pro-autophagic signals. The autophagic response triggered by these pathways can temporarily relieve energy and nutrient shortage, and might contribute to the elimination of toxin by promoting its destruction, or leading to exocytosis of undigestable pore complexes [16]

treated cells was also inhibited by 3-MA. Among possible explanations for the apparent discrepancy between our results and those of Mestre et al. [50] are first that different cell types were investigated in the two studies, and second that we used far lower concentrations of $\alpha$-toxin. Alphatoxin at low concentrations is known to form pores that are selective for monovalent ions, whereas high concentrations may permit influx of calcium [64-66].

To sum, we have shown here that sublethal plasma membrane attack by PFT activates pro-autophagic signals, apparently due to transient nutrient and energy shortage. Evidence is presented that this depends on transmembrane pore formation. Because LC3- and p62-recruitment was not confined to vesicles containing $\alpha$-toxin, the autophagic response observed here may be caused by global cellular starvation and energy loss. The relative contribution of these factors - and possibly of additional ones, like hypoxia [10] - to the accumulation of autophagosomes in perforated cells, or cells infected by PFT-producing bacteria remains to be established. Although autophagy may be life-saving for target cells of PFT (Fig. 8), it might come at a price, because it may promote replication of intracellular S. aureus and possibly persistence in the host, $[51,67,68]$.

Acknowledgments We thank Prof. Yoshimori (Research Institute for Microbial Diseases, Osaka) for the generous gift of pEGFP-LC3. The skilful work of Regina Eberle is highly appreciated. Support from the Deutsche Forschungsgemeinschaft (SFB 490, project D3) is gratefully acknowledged. We thank S. Bhakdi for continuous support and critical comments on the manuscript.

Open Access This article is distributed under the terms of the Creative Commons Attribution Noncommercial License which permits any 
noncommercial use, distribution, and reproduction in any medium, provided the original author(s) and source are credited.

\section{References}

1. Bhakdi S, Tranum-Jensen J (1984) Mechanism of complement cytolysis and the concept of channel-forming proteins. Philos Trans R Soc Lond B Biol Sci 306:311-324

2. Bhakdi S, Tranum-Jensen J (1985) Membrane damage by channel-forming proteins: staphylococcal alpha-toxin, streptolysin-O and the C5b-9 complement complex. Biochem Soc Symp 50:221-233

3. Bhakdi S, Bayley H, Valeva A, Walev I, Walker B, Kehoe M, Palmer M (1996) Staphylococcal alpha-toxin, streptolysin-O, and Escherichia coli hemolysin: prototypes of pore-forming bacterial cytolysins. Arch Microbiol 165:73-79

4. Gonzalez MR, Bischofberger M, Pernot L, van der Goot FG, Freche B (2008) Bacterial pore-forming toxins: the (w)hole story? Cell Mol Life Sci 65:493-507

5. Aroian R, van der Goot FG (2007) Pore-forming toxins and cellular non-immune defenses (CNIDs). Curr Opin Microbiol 10:57-61

6. Huffman DL, Abrami L, Sasik R, Corbeil J, van der Goot FG, Aroian RV (2004) Mitogen-activated protein kinase pathways defend against bacterial pore-forming toxins. Proc Natl Acad Sci USA 101:1000-10995

7. Husmann M, Dersch K, Bobkiewicz W, Beckmann E, Veerachato G, Bhakdi S (2006) Differential role of p38 mitogen activated protein kinase for cellular recovery from attack by pore-forming S. aureus alpha-toxin or streptolysin O. Biochem Biophys Res Commun 344:1128-1134

8. Gurcel L, Abrami L, Girardin S, Tschopp J, van der Goot FG (2006) Caspase-1 activation of lipid metabolic pathways in response to bacterial pore-forming toxins promotes cell survival. Cell 126:1135-1145

9. Bischof LJ, Kao CY, Los FC, Gonzalez MR, Shen Z, Briggs SP, van der Goot FG, Aroian RV (2008) Activation of the unfolded protein response is required for defenses against bacterial poreforming toxin in vivo. PLoS Pathog 4:e1000176

10. Bellier A, Chen CS, Kao CY, Cinar HN, Aroian RV (2009) Hypoxia and the hypoxic response pathway protect against poreforming toxins in C. elegans. PLoS Pathog 5:e1000689

11. Chen CS, Bellier A, Kao CY, Yang YL, Chen HD, Los FC, Aroian RV (2010) WWP-1 is a novel modulator of the DAF-2 insulin-like signaling network involved in pore-forming toxin cellular defenses in Caenorhabditis elegans. PLoS One 5:e9494

12. Walev I, Palmer M, Martin E, Jonas D, Weller U, Hoehn-Bentz H, Husmann M, Bhakdi S (1994) Recovery of human fibroblasts from attack by the pore-forming alpha-toxin of Staphylococcus aureus. Microb Pathog 17:187-201

13. Dragneva Y, Anuradha CD, Valeva A, Hoffmann A, Bhakdi S, Husmann M (2001) Subcytocidal attack by staphylococcal alphatoxin activates NF-kappaB and induces interleukin- 8 production. Infect Immun 69:2630-2635

14. Walev I, Hombach M, Bobkiewicz W, Fenske D, Bhakdi S, Husmann M (2002) Resealing of large transmembrane pores produced by streptolysin $\mathrm{O}$ in nucleated cells is accompanied by NF-kappaB activation and downstream events. Faseb J 16:237-239

15. Idone V, Tam C, Goss JW, Toomre D, Pypaert M, Andrews NW (2008) Repair of injured plasma membrane by rapid Ca2+ -dependent endocytosis. J Cell Biol 180:905-914

16. Husmann M, Beckmann E, Boller K, Kloft N, Tenzer S, Bobkiewicz W, Neukirch C, Bayley H, Bhakdi S (2009) Elimination of a bacterial pore-forming toxin by sequential endocytosis and exocytosis. FEBS Lett 583:337-344
17. Gutierrez MG, Saka HA, Chinen I, Zoppino FC, Yoshimori T, Bocco JL, Colombo MI (2007) Protective role of autophagy against Vibrio cholerae cytolysin, a pore-forming toxin from $V$. cholerae. Proc Natl Acad Sci USA 104:1829-1834

18. Yoshimori T (2004) Autophagy: a regulated bulk degradation process inside cells. Biochem Biophys Res Commun 313:453-458

19. He C, Klionsky DJ (2009) Regulation mechanisms and signaling pathways of autophagy. Annu Rev Genet 43:67-93

20. Stanfel MN, Shamieh LS, Kaeberlein M, Kennedy BK (2009) The TOR pathway comes of age. Biochim Biophys Acta 1790:10671074

21. Avruch J, Long X, Ortiz-Vega S, Rapley J, Papageorgiou A, Dai N (2009) Amino acid regulation of TOR complex 1. Am J Physiol Endocrinol Metab 296:E592-E602

22. Chang YY, Juhasz G, Goraksha-Hicks P, Arsham AM, Mallin DR, Muller LK, Neufeld TP (2009) Nutrient-dependent regulation of autophagy through the target of rapamycin pathway. Biochem Soc Trans 37:232-236

23. Zinzalla V, Hall MN (2008) Signal transduction: Linking nutrients to growth. Nature 454:287-288

24. Talloczy Z, Jiang W, Virgin HWT, Leib DA, Scheuner D, Kaufman RJ, Eskelinen EL, Levine B (2002) Regulation of starvation- and virus-induced autophagy by the eIF2alpha kinase signaling pathway. Proc Natl Acad Sci USA 99:190-195

25. Harding HP, Zhang Y, Zeng H, Novoa I, Lu PD, Calfon M, Sadri N, Yun C, Popko B, Paules R, Stojdl DF, Bell JC, Hettmann T, Leiden JM, Ron D (2003) An integrated stress response regulates amino acid metabolism and resistance to oxidative stress. Mol Cell 11:619-633

26. Wek RC, Jiang HY, Anthony TG (2006) Coping with stress: eIF2 kinases and translational control. Biochem Soc Trans 34:7-11

27. Harding HP, Novoa I, Zhang Y, Zeng H, Wek R, Schapira M, Ron D (2000) Regulated translation initiation controls stress-induced gene expression in mammalian cells. Mol Cell 6:1099-1108

28. Novoa I, Zeng H, Harding HP, Ron D (2001) Feedback inhibition of the unfolded protein response by GADD34-mediated dephosphorylation of eIF2alpha. J Cell Biol 153:1011-1022

29. Balachandran S, Roberts PC, Brown LE, Truong H, Pattnaik AK, Archer DR, Barber GN (2000) Essential role for the dsRNAdependent protein kinase PKR in innate immunity to viral infection. Immunity 13:129-141

30. Berlanga JJ, Ventoso I, Harding HP, Deng J, Ron D, Sonenberg N, Carrasco L, de Haro C (2006) Antiviral effect of the mammalian translation initiation factor 2alpha kinase GCN2 against RNA viruses. EMBO J 25:1730-1740

31. Munn DH, Sharma MD, Baban B, Harding HP, Zhang Y, Ron D, Mellor AL (2005) GCN2 kinase in T cells mediates proliferative arrest and anergy induction in response to indoleamine 2, 3-dioxygenase. Immunity 22:633-642

32. Scheu S, Stetson DB, Reinhardt RL, Leber JH, Mohrs M, Locksley RM (2006) Activation of the integrated stress response during T helper cell differentiation. Nat Immunol 7:644-651

33. Goh KC, deVeer MJ, Williams BR (2000) The protein kinase PKR is required for p38 MAPK activation and the innate immune response to bacterial endotoxin. EMBO J 19:4292-4297

34. Frerichs KU, Smith CB, Brenner M, DeGracia DJ, Krause GS, Marrone L, Dever TE, Hallenbeck JM (1998) Suppression of protein synthesis in brain during hibernation involves inhibition of protein initiation and elongation. Proc Natl Acad Sci USA 95:14511-14516

35. Costa-Mattioli M, Gobert D, Harding H, Herdy B, Azzi M, Bruno M, Bidinosti M, Ben Mamou C, Marcinkiewicz E, Yoshida M, Imataka H, Cuello AC, Seidah N, Sossin W, Lacaille JC, Ron D, Nader K, Sonenberg N (2005) Translational control of hippocampal synaptic plasticity and memory by the eIF2alpha kinase GCN2. Nature 436:1166-1173 
36. Costa-Mattioli M, Gobert D, Stern E, Gamache K, Colina R, Cuello C, Sossin W, Kaufman R, Pelletier J, Rosenblum K, Krnjevic K, Lacaille JC, Nader K, Sonenberg N (2007) eIF2alpha phosphorylation bidirectionally regulates the switch from short- to long-term synaptic plasticity and memory. Cell 129:195-206

37. Saka HA, Gutierrez MG, Bocco JL, Colombo MI (2007) The autophagic pathway: a cell survival strategy against the bacterial poreforming toxin Vibrio cholerae cytolysin. Autophagy 3:363-365

38. Boukamp P, Petrussevska RT, Breitkreutz D, Hornung J, Markham A, Fusenig NE (1988) Normal keratinization in a spontaneously immortalized aneuploid human keratinocyte cell line. J Cell Biol 106:761-771

39. Jursch R, Hildebrand A, Hobom G, Tranum-Jensen J, Ward R, Kehoe M, Bhakdi S (1994) Histidine residues near the N terminus of staphylococcal alpha-toxin as reporters of regions that are critical for oligomerization and pore formation. Infect Immun 62:2249-2256

40. Weller U, Mueller L, Messner M, Palmer M, Valeva A, TranumJensen J, Agrawal P, Biermann C, Dobereiner A, Kehoe MA, Bhakdi S (1996) Expression of active streptolysin O in Escherichia coli as a maltose-binding-protein-streptolysin-O fusion protein. The N-terminal 70 amino acids are not required for hemolytic activity. Eur J Biochem 236:34-39

41. Abdel Ghani EM, Weis S, Walev I, Kehoe M, Bhakdi S, Palmer M (1999) Streptolysin O: inhibition of the conformational change during membrane binding of the monomer prevents oligomerization and pore formation. Biochemistry 38:15204-15211

42. Valeva A, Walev I, Weis S, Boukhallouk F, Wassenaar TM, Endres K, Fahrenholz F, Bhakdi S, Zitzer A (2004) A cellular metalloproteinase activates Vibrio cholerae pro-cytolysin. J Biol Chem 279:25143-25148

43. Dersch K, Ichijo H, Bhakdi S, Husmann M (2005) Fatty acids liberated from low-density lipoprotein trigger endothelial apoptosis via mitogen-activated protein kinases. Cell Death Differ 12:11071114

44. Mundschau LJ, Faller DV (1995) Platelet-derived growth factor signal transduction through the interferon-inducible kinase PKR. Immediate early gene induction. J Biol Chem 270:3100-3106

45. Nikles D, Bach P, Boller K, Merten CA, Montrasio F, Heppner FL, Aguzzi A, Cichutek K, Kalinke U, Buchholz CJ (2005) Circumventing tolerance to the prion protein $(\mathrm{PrP})$ : vaccination with $\mathrm{PrP}$ displaying retrovirus particles induces humoral immune responses against the native form of cellular PrP. J Virol 79:4033-4042

46. Haugwitz U, Bobkiewicz W, Han SR, Beckmann E, Veerachato G, Shaid S, Biehl S, Dersch K, Bhakdi S, Husmann M (2006) Pore-forming Staphylococcus aureus alpha-toxin triggers epidermal growth factor receptor-dependent proliferation. Cell Microbiol 8:1591-1600

47. Hyde R, Taylor PM, Hundal HS (2003) Amino acid transporters: roles in amino acid sensing and signalling in animal cells. Biochem J 373:1-18

48. Walker B, Bayley H (1995) Key residues for membrane binding, oligomerization, and pore forming activity of staphylococcal alpha-hemolysin identified by cysteine scanning mutagenesis and targeted chemical modification. J Biol Chem 270:23065-23071

49. Kloft N, Busch T, Neukirch C, Weis S, Boukhallouk F, Bobkiewicz W, Cibis I, Bhakdi S, Husmann M (2009) Pore-forming toxins activate MAPK p38 by causing loss of cellular potassium. Biochem Biophys Res Commun 385:503-506

50. Mestre MB, Fader CM, Sola C, Colombo MI (2010) Alpha-hemolysin is required for the activation of the autophagic pathway in Staphylococcus aureus-infected cells. Autophagy 6:110-125

51. Schnaith A, Kashkar H, Leggio SA, Addicks K, Kronke M, Krut O (2007) Staphylococcus aureus subvert autophagy for induction of caspase-independent host cell death. J Biol Chem 282:26952706

52. Mizushima N, Yoshimori T, Levine B (2010) Methods in mammalian autophagy research. Cell 140:313-326

53. Viala JP, Mochegova SN, Meyer-Morse N, Portnoy DA (2008) A bacterial pore-forming toxin forms aggregates in cells that resemble those associated with neurodegenerative diseases. Cell Microbiol 10:985-993

54. Meyer-Morse N, Robbins JR, Rae CS, Mochegova SN, Swanson MS, Zhao Z, Virgin HW, Portnoy D (2010) Listeriolysin O is necessary and sufficient to induce autophagy during Listeria monocytogenes infection. PLoS One 5:e8610

55. Dupont N, Lacas-Gervais S, Bertout J, Paz I, Freche B, Van Nhieu GT, van der Goot FG, Sansonetti PJ, Lafont F (2009) Shigella phagocytic vacuolar membrane remnants participate in the cellular response to pathogen invasion and are regulated by autophagy. Cell Host Microb 6:137-149

56. Dever TE, Hinnebusch AG (2005) GCN2 whets the appetite for amino acids. Mol Cell 18:141-142

57. Goossens A, Dever TE, Pascual-Ahuir A, Serrano R (2001) The protein kinase Gcn2p mediates sodium toxicity in yeast. J Biol Chem 276:30753-30760

58. Narasimhan J, Staschke KA, Wek RC (2004) Dimerization is required for activation of eIF2 kinase Gcn2 in response to diverse environmental stress conditions. J Biol Chem 279:22820-22832

59. Kravchenko VV, Kaufmann GF, Mathison JC, Scott DA, Katz AZ, Wood MR, Brogan AP, Lehmann M, Mee JM, Iwata K, Pan Q, Fearns C, Knaus UG, Meijler MM, Janda KD, Ulevitch RJ (2006) N-(3-oxo-acyl)homoserine lactones signal cell activation through a mechanism distinct from the canonical pathogen-associated molecular pattern recognition receptor pathways. J Biol Chem 281:28822-28830

60. Jarry TM, Memmi G, Cheung AL (2008) The expression of alphahaemolysin is required for Staphylococcus aureus phagosomal escape after internalization in CFT-1 cells. Cell Microbiol 10:1801-1814

61. Fader CM, Sanchez D, Furlan M, Colombo MI (2008) Induction of autophagy promotes fusion of multivesicular bodies with autophagic vacuoles in k562 cells. Traffic 9:230-250

62. Duran JM, Anjard C, Stefan C, Loomis WF, Malhotra V (2010) Unconventional secretion of Acb1 is mediated by autophagosomes. J Cell Biol 188:527-536

63. Manjithaya R, Anjard C, Loomis WF, Subramani S (2010) Unconventional secretion of Pichia pastoris Acb1 is dependent on GRASP protein, peroxisomal functions, and autophagosome formation. J Cell Biol 188:537-546

64. Walev I, Martin E, Jonas D, Mohamadzadeh M, Muller-Klieser W, Kunz L, Bhakdi S (1993) Staphylococcal alpha-toxin kills human keratinocytes by permeabilizing the plasma membrane for monovalent ions. Infect Immun 61:4972-4979

65. Jonas D, Walev I, Berger T, Liebetrau M, Palmer M, Bhakdi S (1994) Novel path to apoptosis: small transmembrane pores created by staphylococcal alpha-toxin in T lymphocytes evoke internucleosomal DNA degradation. Infect Immun 62:1304-1312

66. Eichstaedt S, Gabler K, Below S, Muller C, Kohler C, Engelmann S, Hildebrandt P, Volker U, Hecker M, Hildebrandt JP (2009) Effects of Staphylococcus aureus-hemolysin A on calcium signalling in immortalized human airway epithelial cells. Cell Calcium 45:165-176

67. Garzoni C, Kelley WL (2009) Staphylococcus aureus: new evidence for intracellular persistence. Trends Microbiol 17:59-65

68. Sinha B, Fraunholz M (2010) Staphylococcus aureus host cell invasion and post-invasion events. Int J Med Microbiol 300:170 175 